\title{
A CLINICAL APPRAISAL OF THE ADEQUACY OF BRAIN \\ CIRCULATION DURING ANAESTHESIA \\ (WITH PARTICULAR REFERENCE TO CAROTID THROMBOENDARTERECTOMY)
}

\author{
Leonard C. JENKINS, B.A., M.D., C.M., F.R.C.P.(C), \\ AND W. B. ChUnG, M.D., F.R.C.S.(C)
}

ALthough no reliable clinical objective methods of analysing effects of anaesthesia on central nervous system (CNs) performance are presently available, clinical reports continue to accumulate depicting functional deficits in cNs acuity in some patients following general anaesthesia. ${ }^{1}$ At one end of this spectrum an extreme example of this type of cNs alteration is the failure to regain consciousness following general anaesthesia. ${ }^{2}$ More subtle changes are not uncommon. ${ }^{3}$ Surprising differences before and after anaesthesia have been demonstrated to a limited degree by flicker fusion studies. ${ }^{4}$

Normal brain physiology is dependent upon adequate energy supplies of oxygen and glucose, both usually readily transported by adequate brain perfusion. The brain is a highly perfused organ receiving a high proportion ( 13.9 per cent) of the total cardiac output. ${ }^{5}$ Total cerebral blood flow (CBF), as measured by the nitrous oxide ${ }^{6}$ or krypton $85^{7}$ methods is $54 \mathrm{ml} / 100 \mathrm{gm}$ brain tissue/min (range of $40-67$ $\mathrm{ml} / 100 \mathrm{gm} / \mathrm{min}) .{ }^{8}$ Brain reserves of oxygen and glucose are negligible. Because of this minute-to-minute dependency of the cNs upon ready availability of essential nutrients, hypoxia and/or hypoglycaemia of short duration soon lead to irreversible cNs damage. ${ }^{8}$

It would seem imperative, therefore, that anaesthesiologists be able to appraise adequacy of cerebral blood flow periodically by clinically applicable methods. This would be desirable during any general anaesthetic administration but particularly imperative during operative procedures for correction of already precarious brain perfusion, as in carotid thromboendarterectomy.

Various investigative methods of measuring CBF (total and regional) are established, using $\mathrm{N}_{2} \mathrm{O}^{6}$ or a variety of radioactive isotopes. ${ }^{7,9}$ As yet, these are not readily applicable in the usual operating room setting.

This report describes some clinically applicable approaches in appraising the adequacy of $\mathrm{CBF}$ during anaesthesia, with particular reference to 30 patients (out of a total of 100) undergoing carotid thromboendarterectomy.

\section{Methods of Appraising Adequacy of CBF}

Four clinical approaches for appraising and ensuring the adequacy of CBF during anaesthesia for carotid thromboendarterectomy were used: considerations of the general anaesthetic agents and techniques; cardiovascular stability assessment (mean arterial pressure (MAP), central venous pressure (CVP), ECG, ophthalmodynamometry); electroencephalography (EEG); internal jugular venous oxygen tension $\left(\mathrm{Pv}_{\mathrm{O}_{2}}\right)$.

The clinical states of the 30 patients studied are listed in Table I. All the patients 


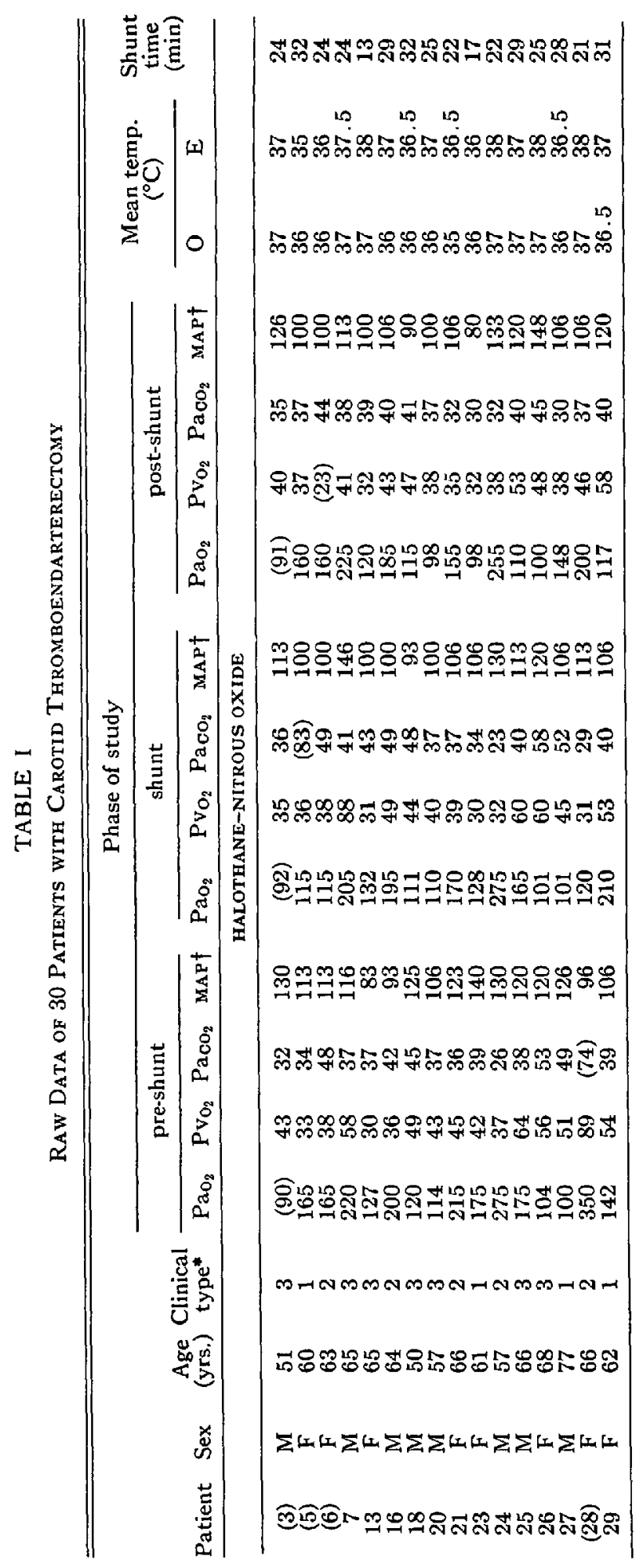




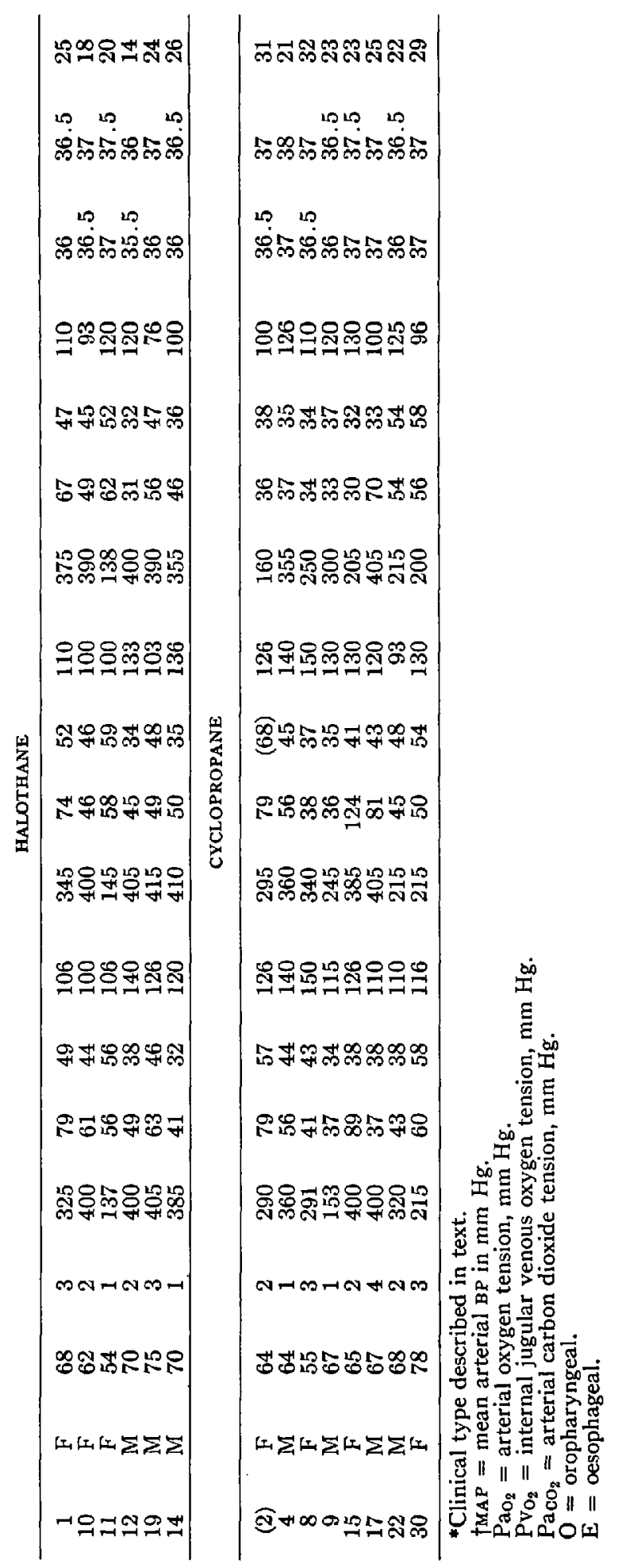


had prior carotid arteriography. In six patients, both carotid vessels were repaired on separate occasions. There were 15 males (mean age 65 years); 15 females (mean age 64 years). The ages ranged from 50 to 78 years (mean 64 years). There were eight patients with no symptoms of cerebrovascular disease prior to operation. These patients were discovered to have significant carotid obstruction on arteriographic examination for some other complaint (clinical type 1 in Table I) ${ }^{10}$ Ten patients had a history of transient ischaemic attacks but no frank stroke (type 2). Eleven patients had completely or partially recovered from a stroke more than eight weeks previously (type 3 ). One patient was operated on shortly after a frank stroke (type 4).

\section{General anaesthetic agents and techniques}

Premedication was either pentobarbital, meperidine, omnopon, or morphine, together with atropine or scopolamine one to two hours prior to operation.

Induction of anaesthesia was with thiopental 100 to $400 \mathrm{mg}$ intravenously. This was followed by succinylcholine 60 to $80 \mathrm{mg}$ intravenously, mPB with 100 per cent oxygen, lidocaine spray to oropharynx and larynx, and oral endotracheal intubation with an armoured cuffed tube (Saunders or Rusch).

Maintenance anaesthesia is summarized in Table I. In eight operations cyclopropane was used; six patients received halothane and oxygen, and 16 patients were given 50:50 $\mathrm{N}_{2} \mathrm{O}: \mathrm{O}_{2}$ and halothane. All patients were given intravenous gallamine as muscle relaxant.

Basic monitoring. Since oxygen utilization by the cNs will vary with body temperature, ${ }^{11}$ attention was given to the maintenance of normal body temperature during operation. On occasion this necessitated use of a heated mattress or elevating the operating room temperature. Oesophageal and nasopharyngeal temperatures were recorded continuously. The mean temperatures are listed in Table I. The ventilation was controlled by an automatic mechanical ventilator (Bird). Precision of ventilation was monitored by reference to the Radford nomogram, ${ }^{12}$ $\mathrm{Pa}_{\mathrm{O}_{2}}, \mathrm{~Pa}_{\mathrm{CO}_{2}}, \mathrm{pH}$ (Radiometer and Instrumentation Laboratories), and tidal volume (TV) and minute volume (Mv) determinations (by Wright respirometry). Planned hypercarbia or prevention of hypocarbia were aimed for, ${ }^{13}$ with modifications dictated by the clinical situation of each patient (e.g. hypertension, hypotension, bleeding, and depth of anaesthesia).

\section{Cardiovascular stability assessment}

All patients had a continuous ECG established and monitored on an oscilloscope. Central venous pressure (CVP) $)^{14}$ and arterial blood pressures (ABP) were recorded. Mean systemic arterial pressure (MAP) (Table I) was calculated by adding $1 / 3$ of the pulse pressure to the diastolic pressure.

Since CBF decreases when systemic arterial pressure falls below a critical level ${ }^{7,15}$ the systolic blood pressure was kept as constant as possible (range, 140 to $160 \mathrm{~mm} \mathrm{Hg}$ ) during anaesthesia. Since the systolic ABP of 23/30 patients was at or above this level before operation, no special measures were required in most patients. In others the desired ABP was obtained by $(a)$ rapid intravenous infusion of 5 per cent dextrose in lactated Ringer's solution or low molecular weight dextran (which also tends to decrease blood viscosity and improve $\mathrm{CBF}$ ), ${ }^{16}$ or $(b)$ 
hypoventilation to a precise degree of hypercarbia and hypertension, or by a combination of $(a)$ and $(b)$. Whole blood transfusion was rarely required in these patients. No patients were given a vasopressor drug during operation. The use of gallamine as a muscle relaxant, with its atropine-like block, prevented any marked reflex bradycardia and hypotension from developing on manipulation of the carotid bifurcation. The deliberate maintenance of mild hypertension accounts for the high MaP noted in Table I in all phases of the study.

Ophthalmodynamometry was performed on nine patients before and after carotid thromboendarterectomy. The technique of ophthalmodynamometry has been well documented. ${ }^{17-20}$ Only diastolic pressures of the retinal artery were measured, as measurements of systolic pressure have a higher source of error when an attempt is made to determine the end point, or when repeated measurements are taken in rapid succession. ${ }^{17}$ Measurements were obtained in three successive positions: supine, sitting, and standing. Three readings were obtained from each eye in each position, alternating right and left eyes as recommended by Calderon and associates.

\section{Electroencephalography (EEG)}

A bipolar, bilateral scalp needle electrode, frontoparietal EEG (Electronics for Medicine) was established in all patients and continuously observed on the oscilloscope during anaesthesia and surgery. In most cases the EEG recordings were obtained just before induction of anaesthesia and in the early postoperative period as well.

\section{Internal jugular venous oxygen tension $\left(\mathrm{Pv}_{\mathrm{O}_{2}}\right)$}

A steady state of anaesthesia was obtained by the time the carotid vessels and internal jugular vein were exposed and isolated. Arterial and jugular venous blood were then sampled simultaneously, approximately 45 minutes after induction of anaesthesia (pre-shunt samples in Table I). A temporary internal shunt was then inserted by the surgeon. The surgical technique has been described in detail.21,22 When the shunt had been functioning for ten minutes, a second set of samples was drawn simultaneously ( shunt sample in Table I). On completion of the carotid endarterectomy, the shunt was removed. The mean duration of temporary shunting was 22 minutes (range 13 to 32 minutes, Table I). Before the closure of the wound, when bleeding had ceased and blood pressure was stable, a third set of samples was obtained, approximately 75 minutes after the onset of anaesthesia (post-shunt sample in Table I).

Each blood sample was drawn anaerobically into heparinized syringes and placed in ice slush. $\mathrm{Pa}_{\mathrm{O}_{2}}, \mathrm{~Pa}_{\mathrm{CO}_{2}}, \mathrm{Pv}_{\mathrm{O}_{2}}$, and $\mathrm{pH}$ were measured within 30 minutes at $38^{\circ} \mathrm{C}$ (Radiometer and Instrumentation Laboratory apparatus).

\section{Results and Discussion}

\section{Internal jugular venous oxygen tension ( $\mathrm{Pv}_{\mathrm{O}_{2}}$ )}

The data of blood gas analysis in all 30 patients are presented in Table I. The deliberate production of hypercarbia in some patients led to some variation in 
$\mathrm{Pa}_{\mathrm{CO}_{2}}$ values. In three patients $(5,28$, and 2$)$, marked hypercarbia occurred during one sampling period. In patient 5 , hypercarbia $\left(\mathrm{PcO}_{2} 83 \mathrm{~mm} \mathrm{Hg}\right)$ was associated with the appearance of premature ventricular contractions. $\mathrm{Pa}_{\mathrm{CO}_{2}}$ values tended to increase during the shunt period compared to the pre-shunt period during 20 of the 30 operations. This reflects the attempt to avoid hypocarbia and reported associated cerebral vasoconstriction (13) during the shunt period. Conversely, $\mathrm{Pa}_{\mathrm{CO}_{2}}$ decreased from the shunt to the post-shunt period in 22 of the 30 operations as a result of increased ventilation deliberately attempting to return $\mathrm{PCO}_{2}$ to control value ranges.

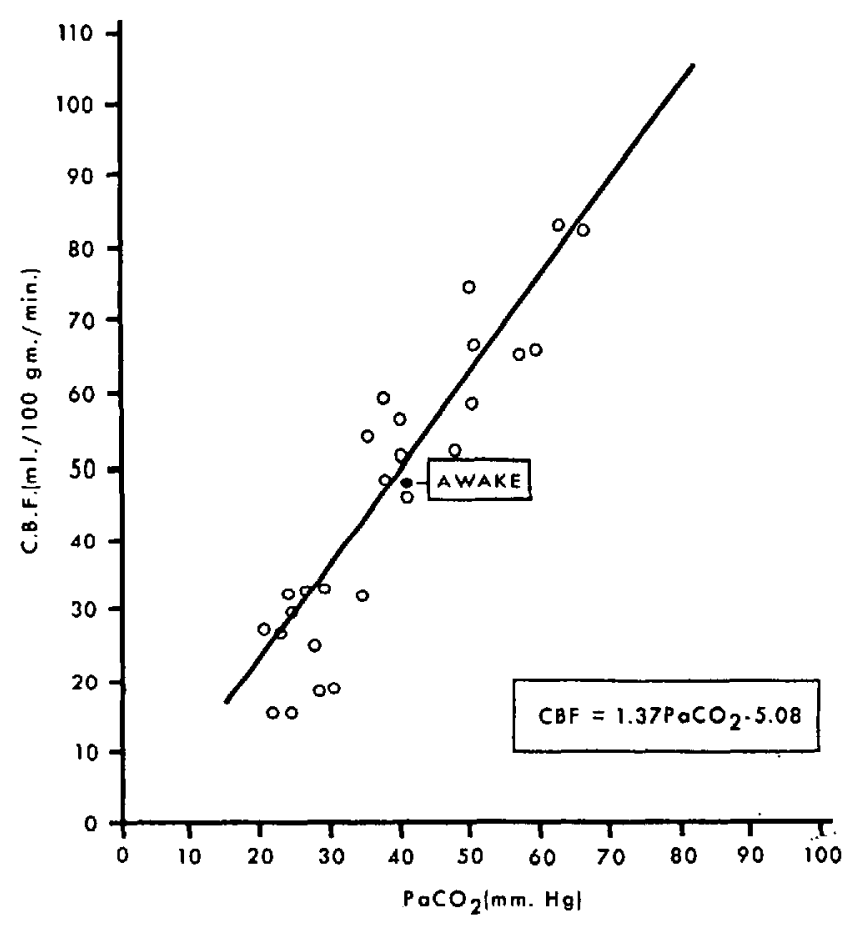

Figure 1. Regression line for $\mathrm{CBF}$ and $\mathrm{Pa}_{\mathrm{CO}_{2}}$. Cerebral blood flow (CBF) as a function of $\mathrm{Paco}_{2}$ during halothane anaesthesia in normal man. The awake point represents the mean value measured by the same method in normal conscious man (44.4 $\mathrm{ml} / 100 \mathrm{gm} / \mathrm{min}$ ). (After Alexander and associates, 1964.31)

Since 50 per cent oxygen or more was inspired by all patients, $\mathrm{Pa}_{\mathrm{O}_{2}}$ values were greater than $100 \mathrm{~mm} \mathrm{Hg}$ in almost all instances except in patient 3 , where $\mathrm{Pa}_{\mathrm{O}_{2}}$ was less than $100 \mathrm{~mm} \mathrm{Hg}$ in all three sampling periods. As expected, $\mathrm{Pa}_{\mathrm{O}_{2}}$ values for patients receiving cyclopropane or halothane were generally higher than for those who received halothane- $\mathrm{N}_{2} \mathrm{O}$, since cyclopropane was given with 70 to 90 per cent oxygen and halothane with 95 to 99 per cent oxygen.

Validity of $\mathrm{Pv}_{\mathrm{O}_{2}}$ as index of $\mathrm{CBF}$

$$
\text { If } \mathrm{CBF} \text { and } \mathrm{Pa}_{\mathrm{CO}_{2}} \text { are related ... }
$$

It is well established that total CBF (as measured indirectly by the $\mathrm{N}_{2} \mathrm{O}^{6}$ or krypton $85^{9}$ techniques, Fig. 1) may be quantitatively related to $\mathrm{Pa}_{\mathrm{CO}_{2}}$ in healthy 
man, either conscious $\left(\mathrm{CBF}=1.31 \mathrm{~Pa}_{\mathrm{CO}_{2}}+7.3\right)^{23}$ or anesthetized $(\mathrm{CBF}=1.37$ $\mathrm{Pa}_{\mathrm{CO}_{2}}$ - 5.08). ${ }^{31}$ This relationship of $\mathrm{CBF}$ and $\mathrm{Pa}_{\mathrm{CO}_{2}}$ has also been confirmed by direct measurements of CBF with thermistor-flowmeter probes placed in both internal jugular veins, where it was demonstrated that an almost linear relationship existed between $\mathrm{CBF}$ and $\mathrm{Pa}_{\mathrm{CO}_{2}}$ values between 20 and $100 \mathrm{~mm} \mathrm{Hg}$ (Fig. 1); ie., as the $\mathrm{Pa}_{\mathrm{CO}_{2}}$ increased from $20 \mathrm{~mm} \mathrm{Hg}$, CBF increased correspondingly. But with $\mathrm{Pa}_{\mathrm{CO}_{2}}$ above $100 \mathrm{~mm} \mathrm{Hg}$, there was little or no further increase in $\mathrm{CBF} .{ }^{24}$

Significantly, in elderly patients with cerebral vascular disease the CBF, during anaesthesia, has been shown to change with $\mathrm{Pa}_{\mathrm{CO}_{2}}$ in a less than normal response. ${ }^{25}$ In one series ${ }^{33} 9$ out of 22 patients with cerebrovascular insufficiency exhibited no appreciable increase in $\mathrm{CBF}$ with inhalation of 5 per cent $\mathrm{CO}_{2}$, in contrast to a significant increase observed in the other 13 patients. These findings would suggest that $\mathrm{Pa}_{\mathrm{CO}_{2}}$ in this type of patient would not provide a consistently reliable index of adequacy of CBF. At the same time, though, since some patients were capable of responding to increased $\mathrm{Pa}_{\mathrm{CO}_{2}}$, deliberate controlled hypercarbia (or at least prevention of hypocarbia) should not be withheld as an adjunct to ensuring adequacy of CBF.

$$
\ldots \text { and } \mathrm{Pv}_{\mathrm{O}_{2}} \text { and } \mathrm{Pa}_{\mathrm{CO}_{2}} \text { are related ... }
$$

Lyons and associates ${ }^{26}$ suggested that the oxygen saturation of jugular venous blood $\left(\mathrm{Sv}_{\mathrm{O}_{2}}\right)$ obtained when the internal carotid artery was clamped for carotid endarterectomy provided a reliable index of the adequacy of the extracranial collateral circulation to the brain. The basis for this recommendation was the wellknown Fick principle applied to the cerebral circulation:

$$
\mathrm{CBF} \propto 1 /\left(a-\mathrm{Sv}_{\mathrm{O}_{2}}\right) \text {. }
$$

CBF is inversely proportional to the arterial-internal jugular venous oxygen difference, if the oxygen requirement (uptake of oxygen or cerebral metabolic rate $\left(\mathrm{CMR}_{\mathrm{O}_{2}}\right.$ ) of the brain is constant ("steady state" of anaesthesia). Assuming 100 per cent oxygen saturation of arterial blood and the same level of haemoglobin in all patients, $\mathrm{Sv}_{\mathrm{O}_{2}}$ should be directly related to $\mathrm{CBF}$. When $\mathrm{Sv}_{\mathrm{O}_{2}}$ was less than 50 per cent, Lyons and associates ${ }^{26}$ recommended the use of a shunt to maintain cerebral circulation during carotid endarterectomy. Clauss and associates ${ }^{27}$ confirmed the observation of Lyons, and both groups reported some patients who suffered neurological damage or symptoms when a shunt was not used and $\mathrm{Sv}_{\mathrm{O}_{2}}$ fell below 50 per cent. Both of these groups of investigators, however, measured internal jugular $\mathrm{Pv}_{\mathrm{O}_{2}}$ and then calculated $\mathrm{Sv}_{\mathrm{O}_{2}}$ from the $\mathrm{O}_{2}$ dissociation curve, corrected for temperature and $\mathrm{pH}$. Recently, Viancos and associates ${ }^{10}$ have established that this is an unnecessary transformation. Their criterion of 50 per cent oxygen saturation can be translated into a $\mathrm{Pv}_{\mathrm{O}_{2}}$ of $28 \mathrm{~mm} \mathrm{Hg}$ at $\mathrm{pH} 7.39$ (the mean $\mathrm{pH}$ of the internal jugular venous blood in these patients studied).

It is of some interest that only one of our $\mathrm{Pv}_{\mathrm{O}_{2}}$ values fell appreciably below $28 \mathrm{~mm} \mathrm{Hg}$. This was in patient 6 (Table I), who had a $\mathrm{Pv}_{\mathrm{O}_{2}}$ of $23 \mathrm{~mm} \mathrm{Hg}$ in the post-shunt sample. She subsequently developed neurological deficits in the immediate postoperative period. This proved to be the result of postoperative thrombosis of the carotid artery. This patient was promptly re-explored and recovered completely. 
Horni and associates ${ }^{28}$ in a similar study of patients undergoing carotid reconstructive operations measured $\mathrm{Pa}_{\mathrm{O}_{2}}, \mathrm{Pv}_{\mathrm{O}_{2}}, \mathrm{pH}$, and haemoglobin. They then calculated oxygen saturation and contents from these values, making allowance for dissolved oxygen, and demonstrated that $\mathrm{Pv}_{\mathrm{O}_{2}}$ (like $\mathrm{CBF}$ ) is inversely proportional to the arterial-internal jugular venous oxygen difference:

$$
\mathrm{Pv}_{\mathrm{O}_{2}} \propto 1 /\left(a-\mathrm{Sv}_{\mathrm{O}_{2}}\right) \text {. }
$$

This also established a relationship between $\mathrm{Pv}_{\mathrm{O}_{2}}$ and $\mathrm{CBF}$.

That there is, indeed, an excellent relationship between $\mathrm{Pv}_{\mathrm{O}_{2}}$ and $\mathrm{Pa}_{\mathrm{CO}_{2}}$ has been confirmed by Viancos and associates ${ }^{10}$ and others ${ }^{6,11,29,31}$ and is also indicated by our results. Figure 2 illustrates regression lines for $\mathrm{Pv}_{\mathrm{O}_{2}}-\mathrm{Pa}_{\mathrm{CO}_{2}}$ relationships as found by Viancos ${ }^{10}$ and ourselves.

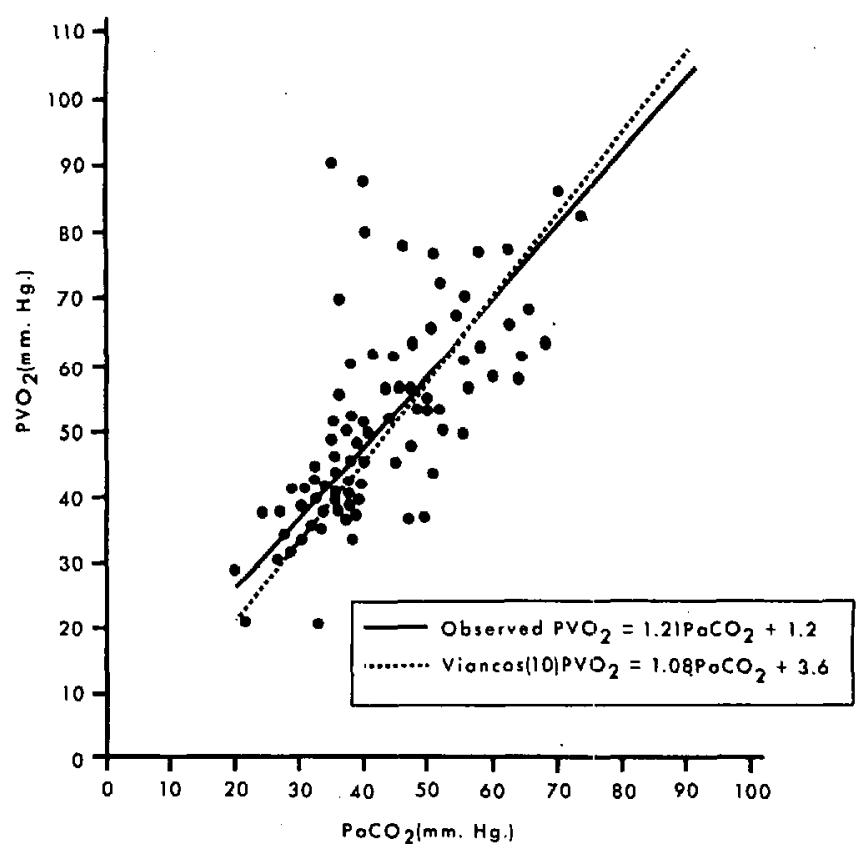

Ficure 2. Regression lines for $\mathrm{Pvo}_{2}$ and $\mathrm{Paco}_{2}$. Relationiship between $\mathrm{Paco}_{2}$ and $\mathrm{Pv}_{\mathrm{O}_{2}}$ in 90 simultaneous samples from 30 anaesthetized patients. The calculated regression equation was $\mathrm{Pvo}_{2}=1.21 \mathrm{PaoO}_{2}+1.2$. The equation derived from data of Viancos 10 is also plotted for comparison: $\mathrm{Pv}_{2}=1.08 \mathrm{Pano}_{2}+$ 3.6.

The 90 pairs of values for $\mathrm{Pa}_{\mathrm{CO}_{2}}$ and $\mathrm{Pv}_{\mathrm{O}_{2}}$ (from Table I) for all sampling periods are plotted in Figure 2. The linear regression equation for this relationship is

$$
\mathrm{Pv}_{\mathrm{O}_{2}}=1.21 \mathrm{~Pa}_{\mathrm{CO}_{2}}+1.2 \text {. }
$$

The slope is statistically significant ( $p$ less than 0.01 ) with a standard error of \pm 0.20 . This equation is remarkably similar to the one derived from the data of Wollman ${ }^{11}$ and Alexander ${ }^{31}$ and their associates for healthy subjects anaesthetized with halothane: $\mathrm{Pv}_{\mathrm{O}_{2}}=1.20 \mathrm{~Pa}_{\mathrm{CO}_{2}}-4.9$, and to that of Viancos ${ }^{10}: \mathrm{Pv}_{\mathrm{O}_{2}}=1.08$ $\mathrm{Pa}_{\mathrm{CO}_{2}}+3.6$, also plotted in Figure 2 . 
The relationship between $\mathrm{PaCO}_{\mathrm{CO}}$ and $\mathrm{Pv}_{\mathrm{O} 2}$ was also analysed according to the period of study (pre-shunt, shunt, and post-shunt, Fig. 3), the anaesthetic agents used (Fig. 4) and the age of the patients (Fig. 5). These relationships are summarized in Table II and plotted as regression lines in Figures 3 to 5 . The regression coefficients for all equations were statistically significant at $p$ less than 0.05 . There was, however, no significant difference between regression means or coefficients for the three curves within the three periods of study, the three anaesthetics, or the three age groups when tested by covariance analysis. ${ }^{32}$

... then CBF and $\mathrm{Pv}_{\mathrm{O}_{2}}$ are related.

Wollman and associates ${ }^{11}$ have demonstrated that a linear relationship exists

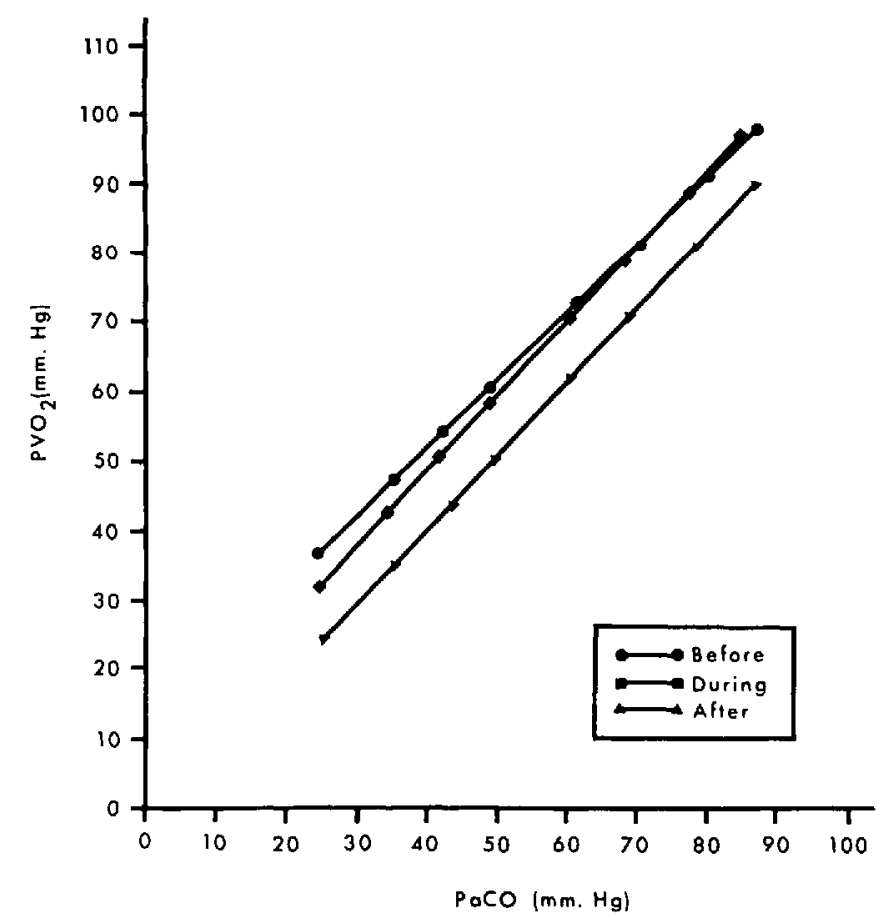

Ficure 3. Relationship between $\mathrm{Paco}_{0}$ and $\mathrm{Pv}_{\mathrm{O}_{2}}$ during three sampling periods. Before, during, and after a temporary internal carotid artery shunt was inserted during carotid endarterectomy. Neither the means nor the slopes of the three regression equations are significantly different from one another.

between $\mathrm{CBF}$ and $\mathrm{Pv}_{\mathrm{O}_{2}}$ during halothane anaesthesia in healthy subjects. They found this relationship to be $\mathrm{CBF}=1.14 \mathrm{Pv}_{\mathrm{O}_{2}}-10.0$ for values of $\mathrm{Pv}_{\mathrm{O}_{2}}$ between 20 and $80 \mathrm{~mm} \mathrm{Hg}$ (Fig. 6).

They suggested, therefore, that measurement of $\mathrm{Pv}_{\mathrm{O}_{2}}$ might be useful for estimating CBF under clinical conditions. They indicated that errors in estimating CBF from internal jugular venous $\mathrm{Pv}_{\mathrm{O}_{2}}$ may arise from the fact that jugular venous $\mathrm{P}_{\mathrm{O}_{2}}$ is determined not only by $\mathrm{CBF}$, but also by $\mathrm{CMR}_{\mathrm{O}_{2}}$, which in turn may be affected 


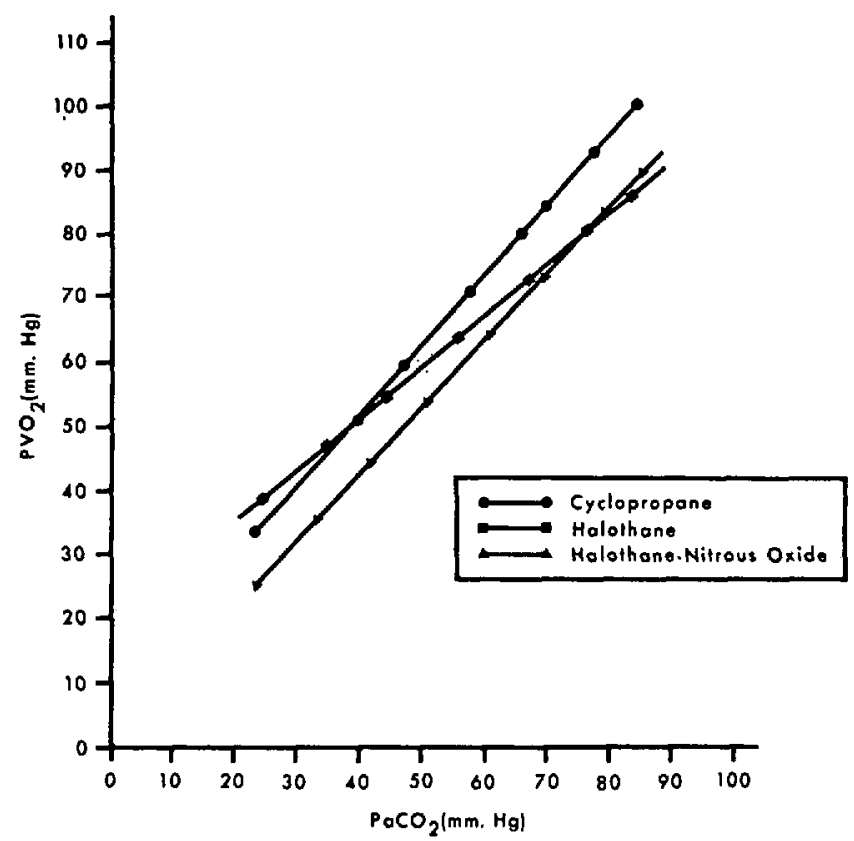

Figure 4. Relationship between $\mathrm{PaaO}_{2}$ and $\mathrm{Pvo}_{2}$ during administration of three types of general anaesthesia. Cyclopropane, halothane-oxygen, and halothane in 50 per cent $\mathrm{N}_{2} \mathrm{O}$ and 50 per cent $\mathrm{O}_{2}$. Neither the means nor the slopes of the three regression equations are significantly different from one another.

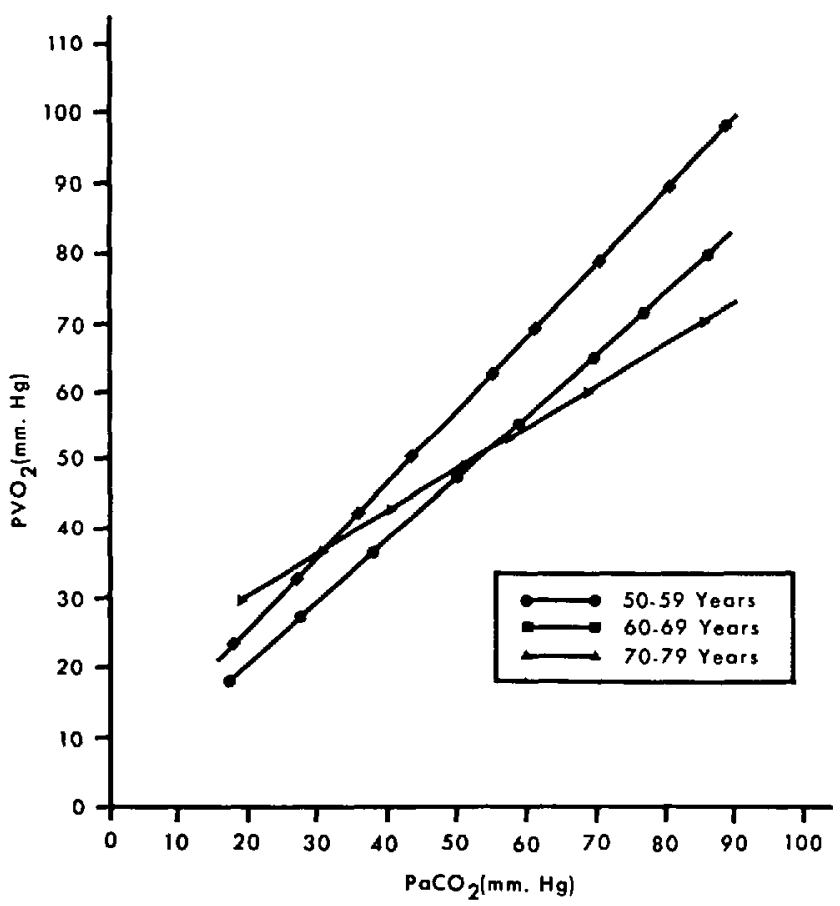

Frgure 5. Relationship between $\mathrm{PaCO}_{2}$ and $\mathrm{Pv}_{\mathrm{O}_{2}}$ in 30 patients undergoing carotid thromboendarterectomy and divided into three age groups. Neither the means nor the slopes of the three regression equations are significantly different from one another. 
JENKINS \& CHUNG: BRAYN CIRCULATION DURING ANAESTHESIA

TABLE II

Regression Coefficients and Standard Errors Relating Paco and Pvo $\mathrm{O}_{2}$ According to Period of Study, Anaesthetic Agents, and Age of Subject

\begin{tabular}{|c|c|c|c|}
\hline & $\mathbf{N}$ & $\begin{array}{c}\text { Regression } \\
\text { equation }\end{array}$ & $\begin{array}{l}\text { Standard error } \\
\text { of regression } \\
\text { coefficients }\end{array}$ \\
\hline $\begin{array}{l}\text { Pre-shunt } \\
\text { Shunt } \\
\text { Post-shunt } \\
\text { Halothane- } \mathrm{N}_{2} \mathrm{O} \\
\text { Halothane } \\
\text { Cyclopropane } \\
70-79 \text { yr. } \\
60-69 \text { yr. } \\
50-59 \text { yr. }\end{array}$ & $\begin{array}{l}30 \\
30 \\
30 \\
48 \\
18 \\
24 \\
15 \\
57 \\
18\end{array}$ & 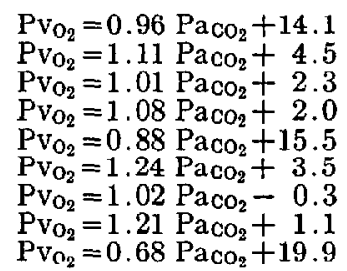 & $\begin{array}{l}0.21 \\
0.29 \\
0.20 \\
0.15 \\
0.25 \\
0.54 \\
0.15 \\
0.21 \\
0.19\end{array}$ \\
\hline
\end{tabular}

by many variables such as age, temperature, anaesthetic drug, and depth of anaesthesia. In our series, $\mathrm{CMR}_{\mathrm{O}_{2}}$ was clinically constant ("steady state" of anaesthesia), and there was light general anesthesia at normal body temperature in a patient group homogenous for age and disease. The results of this study and of that of Viancos ${ }^{10}$ indicate that $\mathrm{Pv}_{\mathrm{O}_{2}}$ provides a reliable index of $\mathrm{CBF}$, even in patients with cerebrovascular disease. This is a more reliable index of $\mathrm{CBF}$ than $\mathrm{Pa}_{\mathrm{CO}_{2}}$, since the relationships between $\mathrm{Pa}_{\mathrm{CO}_{2}}$ and $\mathrm{CBF}$ are invalidated ${ }^{33}$ in 50 per cent of patients with cerebrovascular disease.

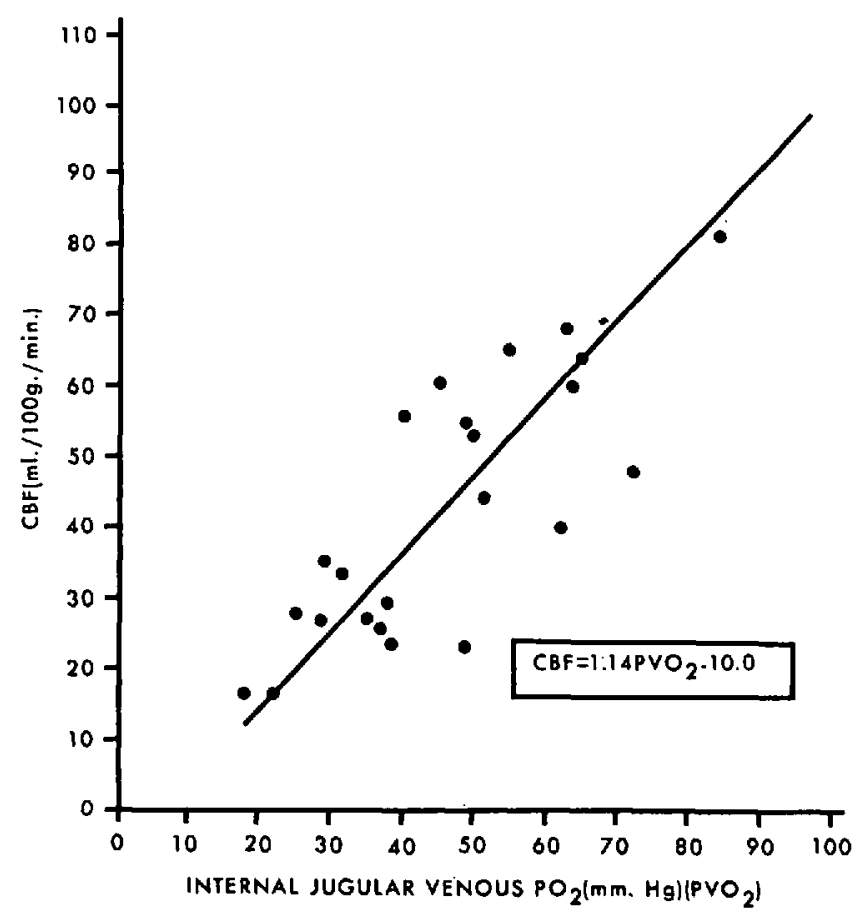

Figure 6. Regression line relating $\mathrm{CBF}$ and $\mathrm{Pv}_{\mathrm{O}_{2}}$. Cerebral blood flow (CBF) as a function of jugular venous $\mathrm{P}_{\mathrm{O}_{2}}\left(\mathrm{Pv}_{\mathrm{O}_{2}}\right)$ during halothane anaesthesia. (After Wollman and associates, 1964.11) 
Our data and that from others ${ }^{10,11,30,31}$ were obtained during general anaesthesia, when subjects or patients were breathing high oxygen mixtures. Does this relationship apply well with $\mathrm{Pa}_{\mathrm{O}_{2}}$ values more or less than the 100 to $400 \mathrm{~mm} \mathrm{Hg}$ range present in their studies and our own? Lambertsen and associates ${ }^{34}$ measured $\mathrm{Pv}_{\mathrm{O}_{2}}$ in healthy subjects breathing air or oxygen at 1.0 and 3.5 atmospheres. They found that even with $\mathrm{Pa}_{\mathrm{O}_{2}}$ values of $1,900 \mathrm{~mm} \mathrm{Hg}$, mean $\mathrm{Pv}_{\mathrm{O}_{2}}$ was only $76 \mathrm{~mm} \mathrm{Hg}$. $\mathrm{Pv}_{\mathrm{O}_{2}}$, therefore, seems to be fairly independent of $\mathrm{Pa}_{\mathrm{O}_{2}}$ values over a wide range. Thus, $\mathrm{Pv}_{\mathrm{O}_{2}}$ can provide a useful measure of $\mathrm{CBF}$ in a wide variety of clinical situations.

\section{Stability during anaesthesia}

Anaesthetic agent and technique. Our results suggest that it does not seem to matter what anaesthetic agent is used. This is demonstrated by our regression equations for $\mathrm{Pv}_{\mathrm{O}_{2}}$ and $\mathrm{Pa}_{\mathrm{CO}_{2}}$ in Figure 4 and Table II. There was indeed a close linear relationship between $\mathrm{Pv}_{\mathrm{O}_{2}}$ and $\mathrm{Pa}_{\mathrm{CO}_{2}}$ for the three types of general anaesthetics used: cyclopropane, halothane-oxygen, and halothane-nitrous-oxide. Neither the means nor the slopes of the three regression equations were significantly different from one another.

Cardiovascular stability. However, what perhaps is important is how that particular agent is used. A "steady state" of anaesthesia with cardiovascular stability is essential. EKG, CVP, and ABP monitoring provided a ready assessment of cardiovascular stability.

Although ophthalmodynamometry proved to be too cumbersome technically to be a useful index of adequacy of CBF during surgery, it was of value in the early postoperative period as a means of accurately assessing the patency of the carotid circulation following thromboendarterectomy. A difference and/or drop of 20 per cent or more between diastolic pressures of the retinal artery indicates definite and significant reduction in blood flow in the ipsilateral carotid system. ${ }^{17-20}$

Of the 30 patients in this study, only nine had ophthalmodynamometry performed before and after thromboendarterectomy. Ophthalmodynamometry was performed during surgery as well as before and after thromboendarterectomy in one patient. Seven of these patients had unilateral carotid arterial disease; the postoperative pressures of the retinal artery returned to normal in six. Symptoms, such as intermittent cerebral dysfunction and transient monocular blindness as well as local bruit and decreased carotid pulsation, were relieved. In one patient there was no change in the postoperative retinal artery diastolic pressure, but symptoms were less frequent. Two patients had bilateral involvement of the carotid artery. In both of these the postoperative pressure of the retinal artery returned to normal on the side of the operation. There is apparently no strict correlation between the improvement of retinal arterial pressure and the relief of symptoms. ${ }^{17}$

cNS stability. Anaesthesia conducted at a "light" level, with near-normal body temperature and adequate systemic arterial blood gas $\mathrm{P}_{\mathrm{O}_{2}}, \mathrm{P}_{\mathrm{CO}_{2}}$ (prevention of hypocarbia), $\mathrm{pH}$, and acid-base balance provided a relatively stable cNs state. Continuous EEG monitoring had limited usefulness as an index of this stability of the ans. 
Others have described the usefulness of EEG monitoring during carotid thromboendarterectomy. ${ }^{35}$ They have reported cases where grossly abnormal EEG changes occurred. These were of the type described as signs of severe cerebral ischaemia. They generally resulted in postoperative neurological deficits. Thus they felt the EEG was useful for the diagnosis of cerebral ischaemia in the operating room and for establishing the prognosis of the postoperative course. In our experience the EEG has proven less valuable, mainly because all of our patients have an internal shunt placed which functions well, as attested by our steady $\mathrm{Pv}_{\mathrm{O}_{2}}$ values during the shunt period. Of the 30 patients studied, the EEG was of real acute value only in one patient. In this instance, the internal shunt became momentarily "kinked." There was an immediate short-lived alteration in EEG activity indicative of ischaemic change. Because of the EEG change this shunt defect was readily recognized and corrected, and the EEG reverted to its control pattern. There was no neurologic deficit in the postoperative period in this patient.

\section{SumMary and Conclusions}

Studies in 30 patients (out of 100 ) having carotid thromboendarterectomy are described.

1. The validity of using internal jugular venous oxygen tension $\left(\mathrm{Pv}_{\mathrm{O}_{2}}\right)$ as a measure of cerebral blood flow (CBF) in these clinical situations was tested in 30 anaesthetized patients from whom 90 paired values of arterial carbon dioxide tensions $\left(\mathrm{Pa}_{\mathrm{CO}_{2}}\right)$ and $\mathrm{Pv}_{\mathrm{O}_{2}}$ were obtained during carotid thromboendarterectomy. A significant relationship, $\mathrm{Pv}_{\mathrm{O}_{2}}=1.21 \mathrm{~Pa}_{\mathrm{CO}_{2}}+1.2$, was obtained over a wide range of $\mathrm{Pa}_{\mathrm{O}_{2}}$ and $\mathrm{Pa}_{\mathrm{CO}_{2}}$ values, indicating that $\mathrm{Pv}_{\mathrm{O}_{2}}$ was a reliable measure of $\mathrm{CBF}$ under these circumstances. Since $\mathrm{CBF}$ has a linear relationship with $\mathrm{Pa}_{\mathrm{CO}_{2}}$, and $\mathrm{Pv}_{\mathrm{O}_{2}}$ is similarly related to $\mathrm{Pa}_{\mathrm{OO}_{2}}$, it follows that $\mathrm{CBF}$ is also related to $\mathrm{Pv}_{\mathrm{O}_{2}}$. The physiological basis and validity of this relationship (Fick principle) is outlined.

No significant differences were found to result from three types of anaesthetic agents used: cyclopropane, nitrous oxide and halothane, and halothane and oxygen. This indicated that any of these three agents provided adequate CBF under the clinical circumstances described in this study.

There were no differences in samples obtained during the use of a temporary internal carotid artery shunt. This indicated that the shunt provided blood flow sufficient to maintain cerebral circulation.

2. Although the anaesthetic agent per se did not appear important, it appeared essential that the conduct of anaesthesia with the agent provide stability. Monitoring of the electrocardiogram, central venous pressure, and arterial blood pressure provided a ready assessment of cardiovascular stability. Ophthalmodynamometry provided a useful means of accurately assessing the patency of the carotid circulation in the early postoperative period following thromboendarterectomy by comparison with the preoperative retinal artery diastolic pressure. It proved too cumbersome a technique to be of value during the surgical procedure.

CNS stability was maintained by attention to "light" adequate general anaesthesia, near-normal body temperature, and adequate systemic arterial blood gas $\mathrm{P}_{\mathrm{O}_{2}}$, $\mathrm{P}_{\mathrm{CO}_{2}}, \mathrm{pH}$, and acid-base balance (with emphasis on the prevention of hypocarbia and tendency towards hypercarbia). 
Continuous EEG monitoring had limited usefulness as an index of this stability and in assessing adequacy of CBF. Because our surgical shunting procedure was effective in all patients studied, as indicated by the stability of our $\mathrm{Pv}_{\mathrm{O}_{2}}$ values during the shunt period, the EEG was also of limited value as a diagnostic index of cerebral ischaemia or a prognostic influence on the ultimate course of the patient postoperatively.

\section{RÉSUMÉ}

Nous avons décrit les études sur trente malades (sur un total de 100) ayant subi une thromboendartériectomie carotidienne.

1. Chez trente malades anesthésiés, chez qui nous avions obtenu des tensions artérielles de gaz carbonique ( $\mathrm{Pa}_{\mathrm{CO}_{2}}$ ) et des $\mathrm{Pv}_{\mathrm{O}_{2}}$ au cours de thromboendartériectomie carotidienne, nous avons évalué la validité d'employer la tension en oxygène du sang de la veine jugulaire interne $\left(\mathrm{Pv}_{\mathrm{O}_{2}}\right)$ pour mesurer le débit sanguin cérébral (CBF) au cours de ces situations cliniques. Sur un grand nombre de valeurs de $\mathrm{Pa}_{\mathrm{O}_{2}}$ et de $\mathrm{Pa}_{\mathrm{CO}_{2}}$, nous avons obtenu une relation significative: $\mathrm{Pv}_{\mathrm{O}_{2}}=1.21 \mathrm{~Pa}_{\mathrm{CO}_{2}}$ +1.2 , indiquant que la $\mathrm{Pv}_{\mathrm{O}_{2}}$ était une mesure fiable du CBF dans les semblables circonstances. Puisque le CBF possède une relation linéaire avec la $\mathrm{Pa}_{\mathrm{CO}_{2}}$ et que la $\mathrm{Pv}_{\mathrm{O}_{2}}$ possède une relation avec la $\mathrm{Pv}_{\mathrm{O}_{2}}$. La base physiologique et la validité de cette relation (principe de Fick) voilà ce que nous décrivons.

Nous n'avons pas trouvé de différences importantes en employant trois types d'agents anesthésiques: le cyclopropane, le protoxyde d'azote et l'halothane, et lhalothane et loxygène. Cela prouve que chacun de ces trois agents procure un $\mathrm{CBF}$ adéquat dans les circonstances cliniques décrites dans cette étude.

Nous n'avons pas observé de différences importantes sur les échantillons prélevés durant l'usage d'une dérivation temporaire de la carotide interne. Cela veut dire que la dérivation procurait un débit sanguin suffisant pour maintenir la circulation.

2. Bien que l'agent anesthésique lui-même ne semble pas important, il nous a semblé essentiel que la conduite de l'anesthésie avec cet agent procure une stabilité. L'évaluation instantanée de la stabilité cardiovasculaire nous a été fournie par le tracé électrocardiographique (ECG), la pression veineuse centrale (CVP) et la pression artérielle (ABP). L'ophtalmodynamométrie procure un moyen utile d'évaluer avec précision la liberté de la circulation carotidienne à la suite de la thromboendartériectomie au cours des suites opératoires immédiates, en faisant la comparaison avec la pression diastolique préopératoire de l'artère rétinienne. Cette technique peut s'avérer utile durant l'opération. Nous avons maintenu la stabilité du covs en ayant soin de maintenir une anesthésie générale adéquate "légère," une température voisine de la normale, et une $\mathrm{Po}_{2}$, une $\mathrm{PCO}_{2}$, un pH et un équilibre acide-base adéquat du sang artériel systémique (en insistant sur la prévention de l'hypocarbie et sur une tendance vers l'hypercarbie).

L'observation du tracé continue de l'Eeg s'est avérée d'une utilité limitée comme index de cette stabilité comme technique d'évaluation d'un CBF adéquat. A cause du fait que notre technique de dérivation chirurgicale a été efficace chez tous les malades étudiés comme l'ont indiqué nos résultats de $\mathrm{Pv}_{\mathrm{O}_{2}}$ qui n’ont pas baissé 
durant la période de dérivation, l'EEg s'est avéré aussi de valeur limitée comme index diagnostic d'ischémie cérébrale ou comme influence prognostique sur l'évolution ultérieure du malade dans les suites opératoires.

\section{REFERENCES}

1. JAMEs, F. M. The Effects of Cyclopropane Anesthesia without Surgical Operation on Mental Functions of Normal Man. Anesthesiology. 30: 264 (1969).

2. Haucen, F. P. Failure to Regain Consciousness after General Anesthesia. Anesthesiology, 22: 657 (1961).

3. Bartholomew, L. G. \& Scholtz, D. A. Reversible Postoperative Neurological Symptoms J.A.M.A. 162: 22 (1956).

4. BERG, O. Flicker Fusion in Cerebral Hypoxia. Acta. Psychiat. Neurol. Scandinav. 33: 21 (1958).

5. DRIPPS, R. D.; Eckenhoff, J. E.; \& VANDaM, L. D. Introduction to Anaesthesia: The Principles of Safe Practice. 3rd ed. Philadelphia \& London: W. B. Saunders (1967).

6. KeTY, S. S. \& Schmit, C. F. The Nitrous Oxide Method for the Quantitative Determination of Cerebral Blood Flow in Man. J. Clin. Invest. 24: 476 (1948).

7. Lassen, N. A. Cerebral Blood Flow and Oxygen Consumption in Man. Physiol. Rev. 39: 183 (1959).

8. TowEr, D. B. Neurochemistry of Epilepsy; Seizure Mechanisms and Their Management: Cerebral Oxidative Metabolism. Springfield, Ill.: Charles C Thomas (1960).

9. LASSEN, N. A. \& Munck, O. The Cerebral Blood Flow in Man Determined by the Use of Radioactive Krypton. Acta. Physiol. Scandinav. 33: 30 (1955).

10. Viancos, J. G.; Sechzer, P. H.; Keats, A. S.; \& DeBakeY, M. E. Internal Jugular Venous Oxygen Tension as an Index of Cerebral Blood Flow during Carotid Endarterectomy. Circulation. 34: 875 (1966).

11. Wollman, H.; Alexander, S. C.; Cohen, P. J.; Chase, P. E.; Melman, E.; \& Behar, M. G. Cerebral Circulation of Man during Halothane Anesthesia. Anesthesiology. 25: 180 (1964).

12. Radpord, E. P., Jr.; Ferris, B. G., JR.; \& Kruete, B. C. Clinical Use of a Nomogram to Estimate Proper Ventilation during Artificial Respiration. New England J. Med. 251: 877 (1954).

13. WeLls, B. A.; KeATS, A. S.; \& Coolex, D. A. Increased Tolerance to Cerebral Ischemia Produced by General Anesthesia during Temporary Carotid Occlusion. Surgery. 54: 216 (1963).

14. Jenkins, L. C. \& Screech, G. Central Venous Pressure Monitoring in Anaesthesia. Canad, Anaesth. Soc. J. 13: 513 (1966).

15. LAssen, N. A. Autoregulation of Cerebral Blood Flow. Circ. Res. Suppl. 1, 15: 201 (1964).

16. Chrtstophersen, E. B.; May, A. G.; De Weese, J. A.; \& Rob, C. G. The Hemodynamic Effect of Low Molecular Dextran in Arteries with Critical Stenosis during Acute Hemorrhage. Surgery. 60: 402 (1966).

17. Calderon, R. G. \& Eisendrey, A. B. Postural Ophthalmodynamometry in the Surgical Management of Occlusive Aortocranial Disease. J. Neurosurg. 22: 30 (1965).

18. Hollenhonst, R. W. Ophthalmodynamometry and Intracranial Vascular Disease. Med. Clin. N. Am. 42: 951 (1958).

19. LiversedGe, L. A. \& SMTth, V. H. The Place of Ophthalmodynamometry in the Investigation of Cerebrovascular Disease. Brain. 84: 274 (1961).

20. Spalter, H. F. Ophthalmodynamometry and Carotid Artery Thrombosis. Am. J. Ophthal. 47: 453 (1959).

21. DeBakey, M. E.; Crawford, E. S.; Morris, G. C., Jr.; \& Cooley, D. A. Surgical Considerations of Occlusive Disease of the Innominate, Carotid, Subclavian, and Vertebral Arteries, Ann. Surg. 154: 698 (1961).

22. Chung, W. B. Carotid Artery Surgery for Cerebrovascular Insufficiency: Experience with 78 Procedures in 60 Patients. Canad. J. Surg. 10: 21 (1967).

23. Shaptro, W.; Wasserman, A. J.; \& Patterson, J. L. Human Cerebrovascular Response Time to Elevation of Arterial Carbon Dioxide Tension. Arch. Neurol. (Chicago). 13: 130 (1965).

24. Rervich, M. Arterial $\mathrm{PCO}_{z}$ and Cerebral Hemodynamics. Am. J. Physiol. 206: 25 (1964). 
25. Adams, J. E.; Smith, M. C.; \& WyLIE, E. J. Cerebral Blood Flow and Hemodynamics in Extracranial Vascular Disease: Effect of Endarterectomy. Surgery. 53: 449 (1963).

26. Lyons, C.; Clanke, L. C., Jr.; McDowell, H.; \& McArthur, K. Cerebral Venous Oxygen Content during Carotid Thrombintimectomy, Ann. Surg, 160: 561 (1964).

27. Clauss, R. H.; Hass, W. K.; \& Ransohoff, J. Simplified Method for Monitoring Adequacy of Brain Oxygenation during Carotid-Artery Surgery. New England J. Med. 273: 1127 (1965).

28. Horni, J.; Humphries, A. W.; Young, J. R.; Beven, E. G.; \& Smart, J. F. Hypercarbic Anesthesia in Cerebrovascular Surgery. Surgery. 59: 57 (1966).

29. KeтY, S. S. \& Sснмшт, C. F. Effects of Active and Passive Hyperventilation on Cerebral Blood Flow, Cerebral Oxygen Consumption, Cardiac Output, and Blood Pressure of Normal Young Men. J. Clin. Invest. 25: 107 (1946).

30. Pattenson, J. L.; Heyman, A.; Battex, L. L.; \& Frgeuson, R. W. Threshold of Response of the Cerebral Vessels of Man to Increase in Blood Carbon Dioxide. J. Clin. Invest. 34: 1857 (1955).

31. Alexander, S. C.; Wollman, H.; Cohen, P. J.; Chase, P. E.; \& Behar, M. Cerebrovascular Response to $\mathrm{PaCO}_{2}$ during Halothane Anesthesia in Man. J. Appl. Physiol. 19: 561 (1964).

32. SneDecor, G. W. Statistical Methods. Fourth ed. Arnes: Iowa State College Press (1946), p. 330 .

33. Fazekas, J. F. \& Alman, R. W. Maximal Dilatation of Cerebral Vessels. Arch. Neurol. (Chicago). 11: 303 (1964).

34. Lambertsen, C. J.; Ewivg, J. H.; Kaugh, R. H.; Gould, R.; \& Straud, M. W. Oxygen Toxicity: Arterial and Internal Jugular Blood Gas Composition in Man during Inhalation of Air, $100 \%$ Oxygen and $2 \% \mathrm{CO}_{2}$ in $\mathrm{O}_{2}$ at 3.5 Atmospheres Ambient Pressure. J. Appl. Physiol. 8: 255 (1955).

35. Penez-Bonja, C. \& Meyen, J. S. Electroencephalographic Monitoring during Reconstructive Surgery of the Neck Vessels. Electroenceph. Clin. Neurophysiol. 18: 162 (1965). 